ACTA THERIOLOGICA

Vøl. 30, 11: 211-218, 1985

\title{
Small Mammal Exploitation of a Forest-clearcut Interface
}

\author{
Gordon L. KIRKLAND, Jr., ${ }^{1}$ Thomas R. JOHNSTON, Jr. ${ }^{1}$ \\ \& Paul F. STEBLEIN ${ }^{2}$
}

\begin{abstract}
Kirkland G. L., Jr., Johnston T. R., Jr. \& Steblein P. F., 1985: Small mammal exploitation of a forest-clearcut interface. Acta theriol., 30, 11: $211-218$ [With 1 Table].

Small mammals were sampled during 14 months in 1982 and 1983 un a $10 \times 16$ station $(3.6$ ha) grid sited such that half was on a recent clearcut and half was in an uncut mixed oak stand in southcentral rennsylvania (USA). Nine species of small mammals were captured, eight of which were taken on both halves of the grid. An average of 3.9 and 3.6 species were taken per month on the clearcut and forest halves, respectively. The monthly Shannon diversity index was significantly greater on the clearcut half (1.38 vs. 1.07$)$. Small mammals also were significantly more abundant on the clearcut half (50.9 vs. 24.6) The three most abundant species differed in the degree to which they moved between halves of the grid. The proportions of individuals taken at three or more stations and which moved across the habitat interface were: eastern chipmunk (Tamias striatus) 7 of 16 individuals $(43.8 \%$ ), white-footed mouse (Peromyscus leucopus) 25 of $86(29.1 \%)$, and the red-backed vole (Clethrionomys gapperi) 0 of $20(0.0 \%)$. The results indicate that the "clearcutting effect" (i.e. increases in the abundance and diversity of small mammals on recent clearcuts) extends to the periphery of such clearcuts. Nevertheless, forest and clearcut small mammal communities are not discrete as evidenced by the frequent movements of individuals of some species across the habitat interface.

$\left[{ }^{1}\right.$ Vertebrate Museum, Shippensburg University, Shippensburg, Pennsylvania 17257 USA; ${ }^{2}$ Department of Forest Biology, SUNY College of Environmental Science and Forestry, Syracuse, New York 13210 USA]
\end{abstract}

\section{INTRODUCTION}

The response of small mammals to clearcutting of North American forests have been studied extensively (Trousdell, 1954; Tevis, 1956; Krull, 1970; Lovejoy, 1975; Kirkland, 1977, 1979; Martell \& Raduanyi, 1977). Assessments of the population and community responses of small mammals to forest clearcutting generally have been based on comparisons between samples obtained from clearcuts and nearby uncut forests. Implicit in such research has been the assumption that investigators sample discrete forest and clearcut small mammal populations. To help meet this assumption, investigators traditionally have endeavored to center their sampling grids in the interiors of clearcuts and adjacent uncut forests. As a consequence, little is known about the characteristics of small mammal communities at the forest-clearcut interface. Two important questions bearing on the methodology normally used to study 
the responses of small mammals to forest clearcutting are: 1) How discrete are forest and adjacent clearcut small mammal communities?, and 2) Is the "clearcutting effect" (i.e. increases in small mammal abundance and diversity on recent clearcuts) detectable at the periphery of recent clearcuts? In an attempt to answer these questions, we established a $16 \times 10$ station, 3.6 -ha sampling grid oriented such that half the stations $(8 \times 10)$ were on a recent mixed deciduous forest clearcut and the other half were in the uncut portion of the stand. Small mammals were sampled on the grid for 14 months in 1982 and 1983. The data collected permitted us to address three questions concerning small mammal exploitation of the region of the forest-clearcut interface: 1) Were there any quantitative or qualitative differences in the small mammal communities on the forest and clearcut halves of the sampling grid?, 2) How much movement of individuals was there between the two distinct habitats represented on the halves of the grid?, and 3) Were there any differences among species in their movements between habitats? Because the two years of our study coincided with years of high followed by low populations of small mammals, we were also able to analyze whether the answers to these questions were affected by population densities.

\section{DESCRIPTION OF THE STUDY SITE}

The study site on South Mountain in south-central Pennsylvania (Cumberland Co., $3.9 \mathrm{~km} \mathrm{~S}, 3.2 \mathrm{~km} \mathrm{E}$ Cleversburg, el $490 \mathrm{~m}$ ) was located in a middle-aged mixed deciduous forest with a southern aspect and a $2-20 \%$ slope. Overstory vegetation in the forest was dominated by chestnut oak (Quercus prinus) with $\mathrm{dbh}$ (diameter at breast height) ranging from 10 to $40 \mathrm{~cm}$. Other overstory species (in order of dominance) included black oak (Q. velutina), pitch pine (Pinus rigida), black gum (Nyssa sylvatica), red maple (Acer rubrum), and sassafras (Sassafras albidum). The understory and ground cover vegetation consisted primarily of mountain laurel (Kalmia latifolia), seedling and sapling black gum, huckleberry (Gaylusaccia baccata), and blueberry (Vaccinium spp.). The average cover at sampling stations of four ground cover components was: open ground-leaf litter $(49.6 \%)$, living ground cover $(40.6 \%)$, logs/branches/stumps $(8.2 \%)$, and rocks $(0.8 \%)$.

During $1979-1980$ a 40.5 -ha portion of this forest was clearcut, and the hardwood sawlogs were removed. Pine snags were left standing at densities of up to 27 snags/ha. As is the usual practice in hardwood forests in the northeastern United States, no reforestation efforts were undertaken on this site following clearcutting. Reforestation on such sites is natural, being dependent upon stump sprout regeneration and germination of in situ seeds. At the time of this study, 3-5 years postcutting, logging residue, which consisted of logs (primarily pitch pine), tree tops, and stumps, covered an estimated $19.3 \%$ of the site. Chestnut oak, regenerating as stump sprouts, was the most abundant tree species, followed in order of decreasing abundance by black gum, sassafras, scrub oak (Q. ilicifolia), red maple, and black oak. Heights of these tree species generally ranged from 2.5 to $3.5 \mathrm{~m}$. Mountain laurel was abundant. Vegetative ground cover (height $<0.5 \mathrm{~m}$ ) covered 
$40.6 \%$ of the clearcut with blueberry and wintergreen accounting for the greatest proportion. Other prevalent ground cover plants included sedges (Carex spp.), greenbriar (Smilax hispida), pilewort (Erechtites hieracifolia), and mosses. Exposed rock was present on $1.6 \%$ of the surface area at trap stations.

\section{METHODS}

A $10 \times 16$ station sampling grid with $15 \mathrm{~m}$ between lines and stations was sited such that half the grid was in the forest and half on the clearcut. Small mammals were sampled on this grid for 3 consecutive nights each month from April through Oetober 1982 and from May through November 1983. Livetrapping was employed during April-September 1982 and May-October 1983 with two Sherman live traps (one large $-7.5 \times 9.0 \times 23.0 \mathrm{~cm}$; one small $-5.0 \times 6.5 \times 16.5 \mathrm{~cm}$ ) set per station. In October 1982 and November 1983 two Museum Special break-back traps per station were used instead of live traps. Live traps were baited with dry rolled oats and snap traps with a mixture of peanut butter and rolled oats. All traps were set within $1 \mathrm{~m}$ of the station marker. Specimens collected by livetrapping were identified to species, marked by toe-clipping, sexed, weighed, measured (total, tail, hind foot lengths), and released at the site of capture. Snap-trapped animals, along with those found dead in live traps, were salvaged, prepared as scientific specimens, and are housed in the Shippensburg University Vertebrate Museum.

The abundance of small mammals on the two halves of the sampling grid was calculated as the number of individuals captured per month. If an individual was captured on both halves of the grid in any particular manth, it was counted in the abundance totals and in the calculation of the indexes of diversity for bcth halves in that month. Nonparametric statistics (Mann-Whitney U, Spearman Rank Correlation) were used in comparisons of abundance and diversity between halves of the grid and also between years.

\section{RESULTS}

The species compositions of the small mammal communities on the two halves of the grid were virtually identical. Of the nine species captured, eight were taken on the clearcut half and nine in the forest, the only difference being the restriction of captures of the southern flying squirrel, Glaucomys volans, to only the forest half of the grid (Table 1). The average number of species taken per month did not differ significantly between the two halves of the grid over the course of the study (Table 1). Beyond these superficial similarities, the small mammal conmunities on the two halves of the sampling grid exhibited significant diferences in abundance and diversity, as measured by the Shannon Index (Shannon and Weaver, 1963). Based on the number of individuals caotured per month, the clearcut half of the grid supported approximately tuice as many small mammals as the forest half (Table 1). This diffe:ence was statistically significant in both 1982 and 1983, as well as overall.

There was a significant decline in small mammal abundance on the sanpling grid between 1982 and 1983. This decline was generalized in 
forest habitats throughout south-central Pennsylvania and was not confined to the sampling grid. Proportionally, the decline was virtually identical on the two halves of the grid. The average number of individuals captured per month decreased $73.4 \%$ on the clearcut half and $74.6 \%$ on the forest half. These data suggest that the two habitats retained the same relative small mammal densities during periods of high and low small mammal abundance.

Table 1

Mean monthly abundance (individuals captured) and diversity of small mammals on clearcut and forest halves of sampling grid. The results of statistical comparisons between habitats and years are indicated by superscript letters. Comparisons are only within rows. The same superscript letters designate values that differ significantly at $p<0.05$.

\begin{tabular}{|c|c|c|c|c|c|c|}
\hline \multirow{2}{*}{ Small mammals } & \multicolumn{3}{|c|}{ Clearcut } & \multicolumn{3}{|c|}{ Forest } \\
\hline & 1982 & 1983 & Overall & 1982 & 1983 & Overall \\
\hline $\begin{array}{l}\text { Peromyscus leucopus } \\
\text { (White-footed mouse) }\end{array}$ & $37.1^{\mathrm{d}}$ & $11.9^{\mathrm{bd}}$ & 24.5 & $30.4^{\mathrm{e}}$ & $4.7^{\text {be }}$ & 14.5 \\
\hline $\begin{array}{l}\text { Clethrionomys gapperi } \\
\text { (Red-backed vole) }\end{array}$ & $31.0^{\mathrm{ad}}$ & $3.9^{\mathrm{bd}}$ & $17.5^{\mathrm{c}}$ & $2.1^{\mathrm{ae}}$ & -be & $1.1^{\mathrm{c}}$ \\
\hline $\begin{array}{l}\text { Tamias striatus } \\
\text { (Eastern chipmunk) }\end{array}$ & $9.1^{\text {ad }}$ & $2.7^{\mathrm{d}}$ & $5.9^{\mathrm{c}}$ & $3.1^{\mathrm{a}}$ & 2.6 & $2.6^{\mathrm{c}}$ \\
\hline $\begin{array}{l}\text { Blarina brevicauda } \\
\text { (Short-tailed shrew) }\end{array}$ & 0.4 & 1.0 & 0.7 & 0.7 & 0.6 & 0.5 \\
\hline $\begin{array}{l}\text { Pitymys pinetorum } \\
\text { (Pine vole) }\end{array}$ & 1.4 & 0.3 & 0.9 & 0.7 & - & 0.4 \\
\hline $\begin{array}{l}\text { Glaucomys volans } \\
\text { (Southern flying squirrel) }\end{array}$ & - & - & - & 0.6 & 1.3 & 0.9 \\
\hline $\begin{array}{l}\text { Sorex fontinalis } \\
\text { (Maryland shrew) }\end{array}$ & 0.9 & 1.4 & 1.1 & 0.1 & 0.7 & 0.4 \\
\hline $\begin{array}{l}\text { Sorex fumeus } \\
\text { (Smoky shrew) }\end{array}$ & - & 0.3 & 0.1 & - & 0.1 & 0.1 \\
\hline $\begin{array}{l}\text { Mustela erminea } \\
\text { (Ermine) }\end{array}$ & 0.1 & - & 0.1 & 0.1 & - & 0.1 \\
\hline $\bar{x}$ Individuals/mo. & $80.4^{\mathrm{a}}$ & $21.4^{\mathrm{b}}$ & $50.9^{c}$ & $39.4^{\mathrm{a}}$ & $10.0^{\mathrm{b}}$ & $24.6^{\mathrm{c}}$ \\
\hline Range ( $\mathrm{N}$ individuals/mo.) & $24-141$ & $8-52$ & $8-141$ & $17-61$ & $1-29$ & $1-61$ \\
\hline $\bar{x}$ No. Species/mo. & 3.7 & 4.0 & 3.9 & 4.1 & 3.0 & 3.6 \\
\hline $\bar{x}$ Shannon Index $(H) / \mathrm{mo}$. & $1.29^{\mathrm{a}}$ & 1.47 & $1.38^{\mathrm{c}}$ & $0.91^{\mathrm{a}}$ & 1.21 & $1.07^{\mathrm{c}}$ \\
\hline $\bar{x}$ Evenness $\left(H / H_{\max }\right) / \mathrm{mo}$. & $0.76^{a}$ & 0.76 & 0.76 & $0.45^{\text {ae }}$ & $0.72^{\mathrm{e}}$ & 0.58 \\
\hline
\end{tabular}

Based on monthly samples, small mammal diversity (Shannon Index) was significantly greater on the clearcut half of the grid overall and in 1982. Owing to the similarity of the richness components for the two halves of the grid, the difference between their Shannon values reflects the subsantially lower evenness component on the fores half of the grid in 1982. Two principal contributors to this low evenness were the overwhelming numerical dominance of the white-footed mouse, Peromyscus leucopus, in 1982, when it averaged $77.2 \%$ of the monthly samples (compared to only $47.0 \%$ in 1983), and the large number of 
instances in which species were represented on the forest half by a single individual in a particular month $(\mathrm{N}=12)$ compared with the clearcut half $(\mathrm{N}=2)$. The lesser numerical dominance of $P$. leucopus in the forest in 1983, coupled with fewer instances of species being represented there by single individuals $(\mathrm{N}=7$ versus $\mathrm{N}=6$ on the clearcut. half) significantly increased the evenness values for the forest half in 1983 compared to 1982 (Table 1).

The data in Table 1 were used to analyze the similarities between the small mammal communities on the two halves of the grid and to assess the degree of shift in community composition between years in each of the two halves. In general, the relative abundances of species in the two habitats were similar. When all nine species were used in a Spearman: Rank Correlation Analysis, the correlation between the relative abundances of species in the two habitats approached statistical significance$\left(r_{s}=0.683, .05<P<.10\right)$; however, when $G$. volans was excluded and only species common to both halves were analyzed, the Spearman correlation was highly significant $\left(r_{s}=0.900, P<.001\right)$. Further comparisons: of the two halves of the grid in each of the two years revealed that their two communities were very similar in 1982 when small mammal. populations were high $\left(r_{s}=.827, P<.02\right)$, but in 1983 when small mammal populations were depressed, there was no significant correlation between the relative abundances of species in the two halves of the grid $\left(r_{s}=.379\right)$. Within habitat comparisons between the two years revealed that on the clearcut, the relative abundances of species were very similar in the two years $\left(r_{s}=.865, P<.01\right)$. In the forest there was: no significant correlation between the relative abundances of species in years of high and low small mammal abundances $\left(r_{s}=.490\right)$.

The three most abundant species, P. leucopus, C. gapperi, and T. striatus, had sufficient multiple captures to permit an assessment of how discrete forest and clearcut populations were. Data from P. leucopus and $T$. striatus revealed that many individuals of these two species moved freely across the clearcut-forest boundary. Based on data from both years, $29.1 \%$ (25 of 86 ) of the Peromyscus and $43.8 \%$ (7 of 16) of the Tamias captured at three or more different stations were taken on both halves of the grid. The data for Peromyscus were similar in the two years. In $198229.1 \%$ (21 of 71 ) of individuals taken at three or more. stations moved across the interface, whereas in 1983 this figure was. $26.7^{\%} \%$ (4 of 14). The comparable values for Tamias in 1982 and 1983 were $36.4 \%$ ( 4 of 11 ) and $60 \%$ (3 of 5), respectively. The small samplesize in 1983 made it difficult to assess the significance of the higher percentage that year. However, when the sample was increased to include individuals taken at two or more different stations, $32.3^{3} \%$ (10 of 31 ) of 
such individuals moved across the interface in 1982, whereas in 1983 the figure was $38.5 \%$ ( 5 of 13 ). In none of these cases was the proportion significantly different between the two years. There appeared to be no directional preference in movements across the habitat interface by either of these species. Of $46 \mathrm{P}$. leucopus taken at two or more stations and that moved between habitats, 20 moved from the clearcut to the forest, 18 from forest to clearcut, 3 from clearcut to forest and returned, and 5 from forest to clearcut and returned. Of 15 such T. striatus, 6 moved from clearcut to forest, 8 from forest to clearcut, and 1 from forest to clearcut and returned.

In contrast to Peromyscus and Tamians, C. gapperi exhibited little movement across the habitat interface. None of the 20 individuals captured at three or more different stations was taken on both halves of the grid. Of the 62 individuals captured at two or more stations, only $3(4 \%)$ moved across the habitat interface. All such interhabitat movements by Clethrionomys occurred in 1982. These data suggest that clearcut and forest populations of C. gapperi were relatively discrete, especially in comparison with those of $P$. leucopus and Tamias.

\section{DISCUSSION}

The data from this study reveal that on recent clearcuts, the "clear"cutting effect" apparently extends to the periphery of the clearcut. Despite the contiguous nature of the clearcut and forest halves of the sampling grid, the clearcut half supported a significantly greater abundance and diversity of small mammals. These data are similar to those reported by Fleet and Dixon (1984) from a sampling grid encompassing the interface of a mature mixed pine-hardwood forest and a 6-year old clearcut planted to loblolly pine $(P$. taeda) in east Texas. They found small mammals on the clearcut half of the grid to be 2.7 times as abundant as those on the forest half. The respective Shannon Indexes for the forest and clearcut halves in this Texas study, 1.302 vs 1.118 , are remarkedly, similar to those we found (Table 1).

Comparisons between the data from 1982 and 1983 provide some insights into how small mammal abundance per se can influence the characteristics of small mammal communities in the two adjacent habitats. The correlation analyses of relative abundance of species revealed that the small mammal communities on the two halves of the grid were much more similar when small mammals were relatively high in 1982 than when they were low in 1983. Whereas the overall proportional decline in small mammal abundance was equivalent on the two halves of the grid, shifts in the relative abundance of individual species on the 
forest half tended to produce greater changes in the rank order of abundance of individual species there. For example, between 1982 and 1983 three species were lost from the forest half (versus only one on the clearcut half), while $G$. volans increased substantially in abundance (Table 1). On the clearcut half, changes in relative abundance between years did not tend to change the ranking of species in the community. This demonstrates how abundance per se can affect conclusions regarding the degree of similarity between small mammal communities.

The results of this research confirm the conventional wisdom of spatially segregating sampling grids when comparing the small mammal communities of clearcuts and adjacent forests. For at least some species, such as P. leucopus and T. striatus, there is a substantial movement of individuals across the forest-clearcut habitat interface. Consequently at the periophery of clearcuts, the forest and clearcut populations of these two species are not discrete. Limited data from other species precluded a greater generalization.

Acknowledgments: For their assistance in various aspects of the field work, associated with this research we acknowledge students in the general ecology, mammalogy, and topics in mammalian biology courses at Shippensburg University and numerous undergraduate and graduate technicians and volunteers at the Vertebrate Museum. Special thanks are extended to $M ., H$. Klinger and T. V. Fleming. A 1982 grant from the Miklausen-Likar Research Fund at Shippensburg University partially defrayed expenses associated with this research. We thank the staff of the Michaux State Forest for providing access to the study site and information on the characteristics of the study area. We also thank Dr. Elmer C. Birney, Bell Museum of Natural History, University of Minnesota, who reviewed a draft of this paper.

\section{REFERENCES}

1. Fleet R. R. \& Dickson J. G., 1984: Small mammals in two adjacent forest stands in East Texas. [In: Proc. "A Workshop in Management of Nongame Species and Ecological Communities", W. C. McComb. ed.]. Univ. Kentucky: 264-269. Lexington.

2. Kirkland G. L., Jr., 1977: Responses of small mammals to the clearcutting of northern Appalachian forests. J. Mamm., 58: 600-609.

3. Kirkland G. L., Jr., 1979: Initial responses of small mammals to clearcutting of Pennsylvania hardwood forests. Proc. Pennsylvania Acad. Sci., 52: 21-23.

4. Krull J. N., 1970: Responses of chipmunks and red squirrels to commercial clearcut logging. New York Fish and Game J., 17: 58-59.

5. Lovejoy D. A., 1975: The effect of logging on small mammal populations in New England northern hardwoods. Occas. Pap. Univ. Connecticut, Biol. Sci. Ser., 2 (17): 269-291.

6. Martell A. M. \& Radvanyi A., 1977: Changes in small mammal populations after clearcutting of northern Ontario black spruce forest. Canadian Field-Nat., 91: $41-46$.

7. Shannon C. E. \& Weaver W., 1963: The mathematical theory of communication. Univ. Illinois Press: $1-117$. Urbana. 
8. Trousdell K. B., 1954: Peak populations of seed-eating rodents and shrews occurs 1 year after loblolly stands are cut. U. S. Forest Service, Southeastern For. Res. Stat. Research Notes, 68: 1-2.

9. Tevis L. P., 1956: Responses of small mammals to logging of Douglas-firi J. Mamm., 37: 189-196.

Accepted, March 8, 1985.

Gordon KIRKLAND., Jr., Thomas R. JOHNSTON, Jr. i Paul F. STEBLEIN

WYKORZYSTANIE PRZEZ MAEE SSAKI GRANICZĄCYCH ZE SOBA SRODOWISK LASU I MŁODNIKA

Streszczenie

Badania prowadzono przez 14 miesięcy (w latach 1982-1983) w poludniowocentralnej Pennsylwanii. Drobne ssaki odławiano na powierzchni 3,6 ha, na której pułapki umieszczono w sieci $10 \times 16$ punktów. Połowa powierzchni znajdowała się na zarastającym zrębie, właściwie już młodniku, a połowa w starym lesie grądowym.

Złowiono 9 gatunków małych ssaków, z których 8 było wspólnych dla obu połówek powierzchni. W ciągu miesiąca łowiło się średnio 3,9 gatunku w młodniku i 3,6 w lesie. Wskaźnik Shannona wyliczony dla wartości miesięcznych był również istotnie większy dla młodnika (1,38 w porównaniu do 1,07$)$. Ilość małych ssaków także była istotnie większa w młodniku (50,9 w stosunku do 24,6$)$. Trzy najliczniejsze gatunki różniły się stopniem przemieszczania się między oboma połowami powierzchni. Udział osobników łowionych $w$ trzech lub więcej miejscach, a które przechodziły przez granicę środowisk, wynosił: Tamias striatus $-43,8 \%$, Peromyscus leucopus - 29,1\%, Clethrionomys gapperi - $0 \%$. Zespoly małych ssaków lasu i młodnika nie są odrębne, na co wskazuje częstotliwość przemieszcza. nia się osobników różnych gatunków z jednego środowiska do drugiego. 